\title{
Citations of Brazilian physical therapy journals in national publications
}

\author{
Renan K. C. Teixeira ${ }^{1}$, Vitor N. Yamaki ${ }^{1}$, Nara M. Botelho ${ }^{1}$, \\ Renato C. Teixeira ${ }^{2}$
}

\begin{abstract}
Background: Quotations in Brazilian journals are mainly obtained from national articles (articles from Brazilian journals); thus, it is essential to determine how frequently these articles reference Brazilian journals. Objective: This study sought to verify how frequently national papers are cited in the references of three Brazilian physical therapy journals. Method: All references for articles published in Fisioterapia em Movimento, Fisioterapia e Pesquisa and Revista Brasileira de Fisioterapia between 2010 and 2012 were evaluated. In particular, the numbers of national articles and international articles (articles from international journals) cited in these references were determined. Results: A total of 13,009 references cited by 456 articles were analyzed, and 2,924 (22.47\%) of the cited works were national articles. There were no significant differences among the three examined years. A total of $36(7.89 \%)$ articles did not cite national articles, whereas $65(13.25 \%)$ articles cited more national articles than international articles. Conclusion: On average, $22.47 \%$ of the works cited by the evaluated articles were national articles. No significant differences were detected among the three analyzed years.
\end{abstract}

Keywords: journal article; impact factor; bibliography.

\section{HOW TO CITE THIS ARTICLE}

Teixeira RKC, Yamaki VN, Botelho NM, Teixeira RC. Citations of Brazilian physical therapy journals in national publications. Braz J Phys Ther. 2014 Jan-Feb; 18(1):88-92. http://dx.doi.org/10.1590/S1413-35552012005000138

\section{Introduction}

In recent years, there has been extraordinary growth in the publication of research articles, a phenomenon that can primarily be attributed to rapid expansion in the training of new researchers ${ }^{1}$. Biomedical fields have directly contributed to this growth; in particular, physical therapy has played an important role in the recent surge in research publishing. For instance, the quantity of randomized clinical studies in physical therapy increased from 1,950 in 1990 to 5,301 in 2010; moreover, in 2011, a total of 15,293 such clinical studies were ongoing ${ }^{2,3}$.

The growth of research in physical therapy is of paramount importance because this research not only enhances knowledge and enables the standardization of procedures but also confirms or refutes experiences that occur in professional practice ${ }^{4}$; ultimately, this research contributes to improving patients' quality of life.

The evaluation of scientific journals is based on impact factor, which is calculated using the relationship between the total number of citations of a journal over the course of a two-year period and the quantity of articles published in the journal in question during the same period. Notably, this metric does not directly evaluate the published articles but only assesses the number of articles published in a journal during a given time interval ${ }^{5}$.

Article citation can be biased due to several factors, including not only an article's title, research affiliations and scientific field but also the research group or specific researchers associated with an $\operatorname{article}^{6,7}$. The citation of an article can also be affected by factors that are not directly related to the article itself, such as the database in which an article is indexed and the language in which an article is published. For instance, an article that is not published in English cannot readily be perused by the entire scientific community; instead, access to this article is restricted to researchers fluent in the language in which the article is published.

Brazil is the primary Latin American country in which physical therapy articles are published ${ }^{8}$. The

\footnotetext{
${ }^{1}$ Department of Scientific Methodology and Biostatistics, Universidade do Estado do Pará (UEPA), Belém, PA, Brazil

${ }^{2}$ Department of Human Movement Science, UEPA, Belém, PA, Brazil

Received: 06/02/2013 Revised: 08/04/2013 Accepted: 09/13/2013
} 
current growth in publishing in this field can be partially attributed to the expansion of stricto sensu ${ }^{9}$ graduate programs offered by public universities, which has resulted in a ninefold increase in $\mathrm{PhD}$ graduates in physical therapy over the course of the prior 10 years ${ }^{10}$. However, this growth in the quantity and quality of publishing in the field of physical therapy has not been reflected by improvement in Brazilian journals ${ }^{11}$. In fact, only three out of ten Brazilian physical therapy journals are indexed in SciELO (Scientific Electronic Library Online), and only one of these journals possesses an impact factor $^{12,13}$.

Although it has been established that the quality of Brazilian journals is rising, various factors continue to limit increases in the number of citations of these journals. For instance, publications in these journals are predominantly in Portuguese; international articles (articles published in international journals) are of higher quality than publications in these journals; and "brain drain" has led to the publication of leading Brazilian research in foreign journals ${ }^{14}$. These factors have restricted access to and citation of Brazilian journals ${ }^{15}$.

Therefore, the objective of this study is to assess how frequently national papers (papers published in Brazilian journals) are cited by evaluating the references of articles published in three Brazilian physical therapy journals.

\section{- Method}

The references of articles published in three Brazilian physical therapy journals (Fisioterapia em Movimento, Fisioterapia e Pesquisa and Revista Brasileira de Fisioterapia) were analyzed. All articles published from 2010 to 2012 were examined, although only articles describing "original research" were evaluated in this study.

The analyses of this study did not consider articles classified as editorials, literature reviews or case studies; articles without references; or letters to the editor. Literature reviews were excluded because they reference articles with a high impact factor, which are primarily international articles. Therefore, the consideration of literature reviews would bias the selection. Articles that satisfied or violated the inclusion criteria were analyzed based on the references of national articles ${ }^{16}$.

In the search protocol of this study, all examined references were evaluated, disregarding references to books or websites and secondhand ( $a p u d$ ) references. The numbers of references to national articles and to international articles as well as the ratio between references to national articles and references to international articles were determined. For each article, this analysis was performed by one author and subsequently confirmed by another author. In cases in which the two authors' analyses disagreed, the origins of referenced articles were verified using journals' websites.

For each examined journal, the number of selfcitations (references to national articles in the journal in question) was analyzed. The total numbers of citations for all three journals and the ways in which the origins of these citations related to not only the examined journals but also national journals as a whole were also examined. These data were obtained from SciELO for each journal.

The distribution of study data was verified using the Shapiro-Wilk test, which indicated that these data were symmetrically distributed. Analysis of variance (ANOVA) was used to compare the effects of intra- and inter-group factors on the ratio between the quantity of national articles cited and the quantity of international articles cited. The null hypothesis was rejected at $\mathrm{p}<0.05$. All data obtained in this study were analyzed using the BioEstat ${ }^{\circledR} 5.3$ software program.

\section{Results}

A total of 13,099 references cited in 456 articles from the three examined journals were analyzed. Thus, on average, $28.52 \pm 8.43$ references were assessed per article. Table 1 presents the average quantity of references per article for each examined year. In particular, this table indicates that in 2012, 2011 , and 2010 , there were $29.86 \pm 9.08,28.05 \pm 8.42$ and $27.76 \pm 7.67$ citations per article, respectively. Among all of the examined references, 2,924 $(22.47 \%)$ references cited national (Brazilian) articles; this value corresponded to an average of $6.41 \pm 5.61$ citations of national articles in each examined article.

Table 2 indicates data obtained for the three examined Brazilian physical therapy journals. For these journals, no significant differences among the three analyzed years were found with respect to the citation of national journals.

However, a significant difference among the three journals was found with respect to the quantity of citations of national articles. In particular, relative to 
Revista Brasileira de Fisioterapia, Fisioterapia em Movimento $(\mathrm{p}<0.001)$ and Fisioterapia e Pesquisa $(\mathrm{p}<0.001)$ cited national articles at significantly higher rates. These p-values reveal that articles in Revista Brasileira de Fisioterapia cite national articles less frequently than articles in the other two examined journals.

Among all of the examined articles, 36 (7.89\%) articles did not refer to any national articles, 65 $(14.25 \%)$ articles cited more national articles than international articles, and two articles $(0.4 \%)$ only cited national articles. No significant differences among the examined journals $(\mathrm{p}=0.96)$ or the analyzed publication years $(\mathrm{p}=0.75)$ were observed. Table 3 indicates the distribution of citations recorded in the SciELO database.

\section{Discussion}

The production of scientific knowledge in Brazil is greatly increasing, with unprecedented levels of research with respect to both quality and quantity. However, this increase has not been appropriately reflected by publications in national journals ${ }^{11,17,18}$.

On average, $22.47 \%$ of the references cited by the evaluated articles were national (Brazilian) articles. A literature review discovered no other studies that investigated the frequency with which national articles were cited in the field of physical therapy. Therefore, it was impossible to determine whether the average percentage of citations involving national articles has increased by comparing the $22.47 \%$ value obtained in this study with the findings of previous studies.

Table 1. Total articles and references analyzed and proportion of articles cited in the three national magazines according to years studied.

\begin{tabular}{ccccc}
\hline Year of publication & Articles analyzed & Percentage & Number of references & Percentage \\
2012 & 143 & $31,36 \%$ & 4,270 & $32.82 \%$ \\
2011 & 167 & $36,62 \%$ & 4,686 & $36.02 \%$ \\
2010 & 146 & $32,02 \%$ & 4,053 & $31.16 \%$ \\
Total & 456 & $100,00 \%$ & 13,009 & $100.00 \%$ \\
\hline
\end{tabular}

Table 2. Total articles and references analyzed and proportion of articles cited in the three national magazines according to the years studied.

Fisioterapia em Movimento

$\begin{array}{ccccc}\text { Year of publication } & \text { Total articles published } & \text { Number of references } & \text { Brazilian articles cited } & \% \\ 2012 & 51 & 1,522 & 412 & 27.06 \% \\ 2011 & 53 & 1,451 & 506 & 34.87 \% \\ 2010 & 35 & 899 & 299 & 33.25 \% \\ \text { Total } & 139 & 3,872 & 1,217 & 31.43 \%\end{array}$

Fisioterapia e Pesquisa

Year of publication Total articles published Number of reference

2012

2011

2010

Total
40

48

47

135
972

1,192

1,222

3,386
Brazilian articles cited

282

285

323

890

Revista Brasileira de Fisioterapia
Year of publication Total articles published

2012

2011

2010

Total
52

66

64

182
Number of references

$$
1,776
$$

2,043

1,932

5,751
Brazilian articles cited

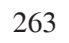

259

265

817

\section{$\%$}

$29.01 \%$

$23.90 \%$

$26.43 \%$

$26.28 \%$ 
Table 3. Distribution of quotes from the three journals.

\begin{tabular}{ccccc}
\hline Magazine & Self-citation & $\begin{array}{c}\text { Quote the Brazilian physical } \\
\text { therapy's periodic }\end{array}$ & $\begin{array}{c}\text { Quote the Brazilian } \\
\text { journal }\end{array}$ & Total quotes \\
FEM & $107-2.76 \%$ & $304-7.85 \%$ & $1.217-31.43 \%$ & 3,872 \\
FEP & $33-0.97 \%$ & $221-6.52 \%$ & $890-26.28 \%$ & 3,386 \\
RBF & $245-4.26 \%$ & $297-5.16 \%$ & $817-14.20 \%$ & 5,751 \\
Total & $385-2.95 \%$ & $822-6.31 \%$ & $2,924-22.47 \%$ & 13,009 \\
\hline
\end{tabular}

Values are expressed in absolute totals and in percentages relative to total citations. FEM: Fisioterapia em movimento; FEP: Fisioterapia e pesquisa; RBF: Revista Brasileira de Fisioterapia.

However, the obtained average may be compared with the results presented by Teixeira et al. ${ }^{16}$, who examined three surgery-related Brazilian journals and determined that on average, $11.65 \%$ of the articles cited by papers in these journals were national articles. Thus, it can be inferred that the authors of Brazilian physical therapy articles cite national articles more frequently than Brazilian surgeons ${ }^{19}$. This difference may be attributed to the fact that more international journals are available in surgery than in physical therapy; as a result, the probability of citing international articles rather than national articles is greater in the former field than in the latter field.

Several factors restrict the citation of Brazilian articles in international journals. First, numerous Brazilian researchers publish only in Portuguese; as a result, their articles cannot be read and cited by researchers in many other nations. Moreover, several articles can only be accessed through local platforms, such as Lilacs ${ }^{20,21}$; this limitation constitutes another obstacle that restricts access to these articles. Among the examined journals, only Revista Brasileira de Fisioterapia publishes all of its articles in English; unsurprisingly, this publication is also the only journal with an impact factor ${ }^{13,14}$.

Another factor that limits the citation of national articles is research quality. Many contributions to Brazilian journals involve the use of small samples to describe local phenomena; therefore, no extrapolation from the results of these studies is possible. Large national studies, such as multicenter clinical trials, are typically published in international journals, resulting in a "brain drain" in which the highestquality national articles typically contribute to the impact of international journals rather than Brazilian journals $^{22-24}$.

It is necessary to perform more studies to determine whether a Brazilian researcher cites national articles in similar ways in articles published in national and international journals. These studies would enable the investigation of correlations involving impact factor, allowing researchers to discover whether a relationship exists between the quality of a journal and the quantity of national articles cited by publications in the journal in question.

\section{Conclusions}

On average, $22.47 \%$ of the references cited by the evaluated articles were national (Brazilian) articles. No significant differences among the analyzed years or the examined journals were detected.

\section{Referências}

1. Brasil. Ministério da Ciência e Tecnologia. Participação percentual do número de artigos brasileiros publicados em periódicos científicos indexados pela Thomson/ISI e Scopus em relação ao mundo, 1996-2011. Brasília: Ministério da Ciência e Tecnologia, 2012 [cited 2012 Nov 28]. Available from: http://www.mct.gov.br/index. php/content/view/5711.html.

2. Maher CG, Moseley AM, Sherrington C, Elkins MR, Herbert RD. A description of the trials, reviews, and practice guidelines indexed in the PEDro database. Phys Ther. 2008;88(9):1068-77. http://dx.doi.org/10.2522/ ptj.20080002

3. Costa LOP, Maher CG, Lopes AD, Noronha MA, Costa LCM. Transparent reporting of studies relevant to physical therapy practice. Rev Bras Fisioter. 2011;15(4):267-71. http://dx.doi.org/10.1590/S1413-35552011005000009

4. Sturmer G, Viero CCM, Silveira MN, Lukrafka JL, Plentz RDM. Profile and scientific output analysis of physical therapy researchers with research productivity fellowship from the Brazilian National Council for Scientific and Technological Development. Braz J Phys Ther. 2013;17(1):41-8. PMid:23538457. http://dx.doi. org/10.1590/S1413-35552012005000068

5. Botelho NM, Teixeira RKC, Yamaki VN. Valorize a pesquisa brasileira: cite os periódicos científicos nacionais. Rev Para Med. 2012;26(3):5-6.

6. Paiva CE, Lima JPSN, Paiva BSR. Articles with short titles describing the results are cited more often. Clinics. 2012;67(5):509-13. http://dx.doi.org/10.6061/ clinics/2012(05)17 
7. Moed HF. Measuring contextual citation impact of scientific journals. J Informetr. 2010;4(3):265-77. http:// dx.doi.org/10.1016/j.joi.2010.01.002

8. Marques AP. Pós-graduação e produção de conhecimentos em Fisioterapia na América Latina: qual é o papel do Brasil? Fisioter Pesqui. 2012;19(3):195. http://dx.doi. org/10.1590/S1809-29502012000300001

9. Demo P. Qualidade e pesquisa na universidade. RBDEPA. 2009;1(1):52-64.

10. Coury HJCG, Vilella I. Profile of the Brazilian physical therapy researcher. Rev Bras Fisioter. 2009;13(4):356-63. http://dx.doi.org/10.1590/S1413-35552009005000048

11. Krzyzanowski RF, Ferreira MCG. Avaliação de periódicos científicos e técnicos brasileiros. Cienc Inf. 1998;27(2):165-75.

12. Thomson Reuters. ISI Web of Knowledge Web site. 2011 [cited 2012 Nov 29]. Available from: http://wokinfo.com/.

13. SciELO. Lista de periódicos indexados. 2012 [cited 2012 Nov 28]. Available from: http://www.scielo.br/scielo. php?lng=pt.

14. Cavalcante RA, Barbosa DR, Bonan PRF, Pires MBO, Martelli-Júnior H. Perfil dos pesquisadores da área de odontologia no Conselho Nacional de Desenvolvimento Científico e Tecnológico (CNPq). Rev Bras Epidemiol. 2008;11(1):106-13. http://dx.doi. org/10.1590/S1415-790X2008000100010

15. Pinto AC, Andrade JB. Fator de impacto de revistas científicas: qual o significado deste parâmetro? Química Nova. 1999;22(3):448-53. http://dx.doi.org/10.1590/ S0100-40421999000300026

16. Teixeira RKC, Silveira TS, Botelho NM, Petroianu A. Citação de artigos nacionais: a (des)valorização dos periódicos brasileiros. Rev Col Bras Cir. 2012;39(5):4214. http://dx.doi.org/10.1590/S0100-69912012000500015

17. Moser ADL. Editorial. Fisioter Mov. 2010;23(3):347-8.

18. Sampaio RF, Salvini TF. Challenges for the advance of physical and occupational therapy research. Rev Bras
Fisioter. 2011;15(5):4-5. http://dx.doi.org/10.1590/ S1413-35552011000500001

19. Guimarães JA. A pesquisa médica e biomédica no Brasil. Comparações com o desempenho científico brasileiro e mundial. Ciênc Saúde Coletiva. 2004;9(2):303-27. http:// dx.doi.org/10.1590/S1413-81232004000200009

20. Lira RPC, Vieira RMC, Gonçalves FA, Ferreira MCA, Maziero D, Passos THM, et al. Influence of English language in the number of citations of articles published in Brazilian journals of Ophthalmology. Arq Bras Oftalmol. 2013;76(1):26-8. http://dx.doi.org/10.1590/ S0004-27492013000100008

21. Van Leeuwen TN, Moed HF, Tijssen RJW, Visser MS, Van Raan AFJ. Language biases in the coverage of the Science Citation Index and its consequences for international comparisons of national research performance. Scientometrics. 2001;51(1):335-46. http:// dx.doi.org/10.1023/A:1010549719484

22. Coura JR, Willcox LC. Impact factor, scientific production and quality of Brazilian medical journals. Mem Inst Oswaldo Cruz. 2003;98(3):293-7. http://dx.doi. org/10.1590/S0074-02762003000300001

23. Lustosa LA, Chalco MEP, Borba CM, Higa AE, Almeida RMR. Citation distribution profile in Brazilian journals of general medicine. São Paulo Med J. 2012;130(5):314-7. http://dx.doi.org/10.1590/S1516-31802012000500008

24. Petroianu A. Perversidade contra a publicação médica no Brasil. Rev Col Bras Cir. 2011;38(5):290-1. http://dx.doi. org/10.1590/S0100-69912011000500001

\section{Correspondence}

\section{Renan Kleber Costa Teixeira}

Rua dos Mundurucus, 225, ap. 1401, Batista Campos

CEP 66035-360, Belém, PA, Brazil

e-mail: renankleberc@hotmail.com 